\title{
The sociodemographic characteristics and dietary and blood plasma fatty acid profiles of elderly Saudi women with Alzheimer disease
}

\author{
Samar Rashed Alsumari ${ }^{1}$, Doha Mustafa AlNouri ${ }^{*}$, Mervat Mohamed Ali El-Sayed ${ }^{1}$, \\ Mohamed Fekry Serag El-Din ${ }^{1,2}$ and Shaista Arzoo ${ }^{1}$
}

\begin{abstract}
Background: Alzheimer's disease (AD) is a progressive neurodegenerative disease, and due to various physiological and psychological factors the patients are at risk of nutritional insufficiencies. The purpose of this study was to assess the dietary fatty acid intake and its effect on plasma fatty acids in elderly Saudi women and to compare the differences in their food and plasma fatty acid profile on the basis of their residence.

Methods: A total of 76 elderly women (50-100 years) were recruited through a random sampling method. A structured proforma was designed to gather information related to their age, income, dietary habits, and presence of any disease and awareness of AD. A 24-h dietary recall method for 3 days and food frequency questionnaire, concentrating on fish consumption and consumption of foods rich in $\omega-3$ fatty acids, which was planned by dietitians, was used for dietary assessment. The gathered data were then analyzed using food processor software. The blood samples were collected to determine plasma fatty acids.

Results: The mean age of women diagnosed with AD was more than 75 years, and the prevalence of illiteracy was higher among AD subjects. As compared to the AD group, the concentration of LA and total $\omega-6$ was significantly $(p \leq 0$. 05) higher in the control group from both recruitment sites [National Guard Health Affairs, King Abdulaziz Medical City, Riyadh (NGH) and Social Welfare Homes for the Elderly (SWH)]. Similarly, the concentrations of EPA, DHA, and $\omega-3$ were also slightly higher in the control group at both sites, but the difference between the control and AD subjects was only significant $(p \leq 0.05)$ in subjects from NGH. We found no significant difference in the $\omega-6 / \omega-3$ ratio between groups. Also, no significant difference was found in the mean level of the plasma fatty acid when comparing the control and AD groups. The concentration of DHA in controls only and AA, EPA and $\omega-6$ in both control and AD were significant (although weakly) correlated with their respective dietary intakes. No correlations were found between the intake of $18 \mathrm{C}$ precursors (LA and ALA) and plasma levels of their long chain derivatives (AA, EPA, and DHA). Education, income, overall health status and the concentration of various fatty acids from food was higher and better in subjects from SWH than NGH. The lower plasma level indicates lower impaired systemic availability of several nutrients.
\end{abstract}

Conclusion: We found that dietary intervention might play a role in the prevention of AD.

Keywords: Alzheimer, Fatty acids, Brain, Plasma, Correlation, Diet

\footnotetext{
* Correspondence: dohaalnouri@gmail.com

'Department of Food and Nutrition Sciences, College of Food and

Agriculture Sciences, King Saud University, Riyadh-11495, P.O. 11495, Riyadh,

Saudi Arabia

Full list of author information is available at the end of the article
}

(c) The Author(s). 2019 Open Access This article is distributed under the terms of the Creative Commons Attribution 4.0 International License (http://creativecommons.org/licenses/by/4.0/), which permits unrestricted use, distribution, and reproduction in any medium, provided you give appropriate credit to the original author(s) and the source, provide a link to the Creative Commons license, and indicate if changes were made. The Creative Commons Public Domain Dedication waiver (http://creativecommons.org/publicdomain/zero/1.0/) applies to the data made available in this article, unless otherwise stated. 


\section{Background}

Alzheimer disease's (AD) is a progressive multifarious neurodegenerative disorder, characterized by intracellular neurofibrillary tangles and extracellular amyloidal protein deposits contributing to senile plaques [1, 2]. The threat of developing $\mathrm{AD}$ is rising exponentially with age and is the main cause of dementia and the most common neurodegenerative disease in the elderly [3]. Oxidative stress and inflammation are the underlying mechanisms of AD pathology [4]. The number of AD suffers is expected to reach 106.8 million worldwide by the year 2050. Therefore, it is a growing public health concern and a major socioeconomic burden [5]. The most common symptoms shown by AD patients include memory loss, along with impairment in reasoning, visual perception, language ability or attention [6].

The human brain is primarily lipid with $22 \%$ of the cerebral cortex and $24 \%$ of white matter comprising of phospholipids. Although the brain proteins are fixed by the genetic code, the fatty acid composition of the brain phospholipids can be modified. Several mechanisms have been proposed for the defensive role of omega 3 fatty acid in dementia. First, sufficient omega-3 fatty acid might help sustain integrity and neuronal function. Second, DHA amends the expression of genes that regulate a variety of biological functions or cognitive health, including neurogenesis and neuronal function. Third, the oxidative products of PUFAs act as key cellular mediators of inflammation, oxidative stress, allergy and immunity, vascular responses, and thrombosis [7]. Studies have revealed that dietary deficiency of n-3 fatty acid or linoleic acid together with linolenic acid leads to decreased brain phospholipid arachidonic acid and
DHA, with concomitant rises in brain n-9 and n-7 MUFAs and PUFAs [8-10]. Although various studies have been conducted to examine the relationships between dietary fat intake and the development of $\mathrm{AD}$, results have been inconsistent as; some have reported strong evidence of association while others have not [11-13]. The main purpose of this study was to assess the dietary fatty acid intake and its effect on plasma fatty acids in elderly Saudi women with and without $\mathrm{AD}$, and to compare the differences in their food and plasma fatty acid profile on the basis of their shelter/residence.

\section{Materials and methods Research design}

A descriptive cross-sectional study approach was used to assess the dietary fatty acid intake and its effect on plasma fatty acids in elderly women.

\section{Sample and sampling technique}

A total of 76 elderly women (50-100-years-old) were recruited through a random sampling method (Fig. 1). A hospital [National Guard Health Affairs, King Abdulaziz Medical City, Riyadh (NGH)] and an old age home Social Welfare Homes for the Elderly (SWH)] were randomly selected, and a survey was made to identify the women of the required age. Then, through a lottery method, the desired sample of women was chosen by a person aware of the study aims [14].

\section{Inclusion and exclusion criteria}

Women between 50 and 100-years-old, non smokers were included in the study. All of the women more than

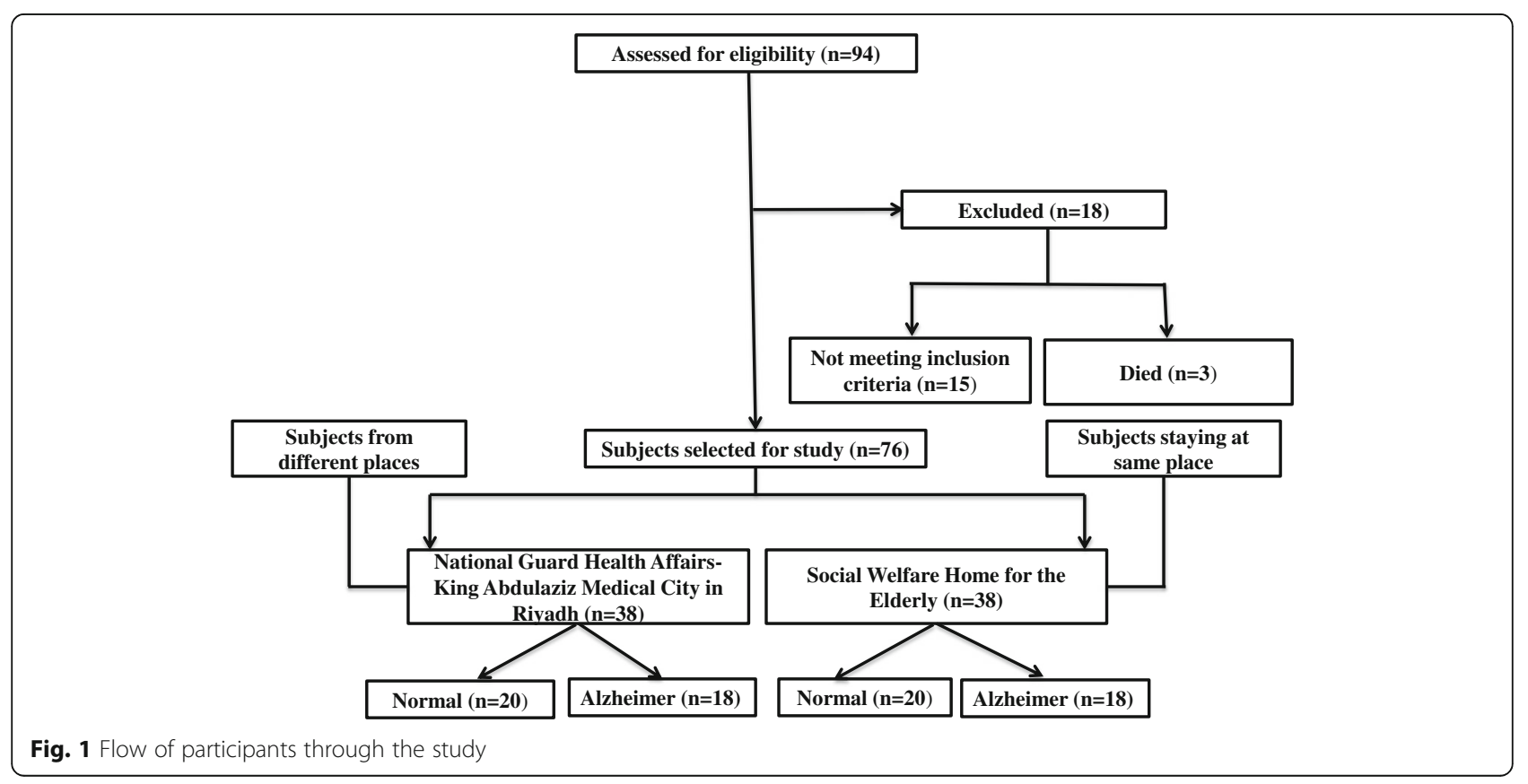


50- and less than 100-years-old, smokers, and women taking any supplementation were excluded from this study.

\section{Demographic characteristics}

A structured proforma was designed and completed with subjects consent while interviewing them to get their demographic information. Their names were not required on the questionnaire and subjects were assured that the information given was entirely for scientific purposes and would be kept confidential. A set of multiple-choice questions related to their age, income, the presence of any disease, awareness of $\mathrm{AD}$, and consumption of certain omega 3, 6 and 9 fatty acid [approved by a panel of experts (in Arabic)] were used to record the data.

\section{Anthropometric measurements}

Height and weight (mentioned on the record book of subjects) were used to calculate BMI using the formula: BMI = weight $(\mathrm{kg}) /$ height $^{2}(\mathrm{~m})^{2}$. The women were classified as underweight if their BMI was $<18.5$, normal if it was between 18.5 and 24.9, overweight if it was 25-29.9, and obese if their BMI was greater than 30 [15].

\section{Dietary assessment}

A 24-h dietary recall method for 3 days and food frequency questionnaire, concentrating on fish consumption and consumption of foods rich in $\omega-3$ fatty acids, as planned by dietitians, was used for dietary assessment, which was then analyzed using food processor software. Subjects were interviewed by the nutritionist to report all food and beverages they had consumed during $24 \mathrm{~h}$ (for 3 days). Then, each item was described as much as possible. The subjects were instructed to report everything eaten or drunk for the past $24 \mathrm{~h}$. The questionnaire included details regarding the exact portion of the food consumed (serving size), type of food (such as low fat, full fat, skimmed, sugar free, fortified), the method of preparation (boiled, deep-fried, baked, grilled), the parts consumed (whole, half, quarter), and the brand name (commercial, ready to eat) [16-18].

\section{Collection of blood samples}

The blood samples were collected after 12-h fasting in lithium heparin tubes and centrifuged at $2500 \mathrm{rpm}$ for 5 min in a megafuge. After centrifugation, the supernatant was separated and stored at $-80^{\circ} \mathrm{C}$ for further analysis.

\section{Methylation and identification of fatty acids (FA)}

Samples were prepared and analyzed according to the method described by Folch et al. [19]. Identification of the individual FA methyl esters was achieved using reference standards. Standards of fatty acids were purchased from Sigma-Aldrich. The FA composition was analyzed using a gas chromatograph (Agilent, GC Mass 6890 model, Schimadza Co. Japan). The gas chromatographic parameters were as follows: Column, fused silica capillary (omegawax, HP-5MS, $30 \mathrm{~m} \times 0.25 \mathrm{~mm} \times 0.25 \mathrm{~mm}$ ); Carrier gas, Helium, $1 \mathrm{ml} / \mathrm{min}$; Detector, M/S -Agilent, $250^{\circ} \mathrm{C}$; Programming temperature, $70-280^{\circ} \mathrm{C}$, after 2 min increased at $20^{\circ} \mathrm{C} / 2 \mathrm{~min}$ to the maximum $280^{\circ} \mathrm{C}$.

\section{Statistical analysis}

Data were analyzed using the SPSS statistical software package and expressed as the mean \pm standard deviation. The differences among the dietary treatment groups were analyzed by one-way ANOVA at a significance level of $p \leq 0.05$. If significant differences were found, a post-hoc analysis using Duncan's multiple range tests was performed.

\section{Results}

\section{Sociodemographic data and dietary habits of studied} subjects

Table 1 depicts the socio-demographic and health characteristics and dietary habit of the studied samples. The mean age of women diagnosed with $\mathrm{AD}$ was more than 75 years, and the mean age of women from the control group was less than 75 years. The BMI of subjects suffering from $\mathrm{AD}$ was less than in the control group. Similarly, the prevalence of illiteracy was higher among women suffering from AD. None of the studied subjects had a degree higher than intermediate. Financially, subjects from the control groups were more stable than the AD patients. For all groups, the most prevalent systemic diseases were diabetes and hypertension, followed by heart disease. Almost 39\% of the AD subjects from NGH had both diabetes and blood pressure, and this proportion was $44.44 \%$ for the AD subjects from SWH, both of which are greater than the control group $(20 \%$ from NGH and 40\% from SWH). Although women from the control groups were aware of AD and $\omega-6$ and $\omega-3$, none of the AD patients had heard these words. Education level, income, and overall health status were higher and better in subjects from SWH.

It can be observed from Table 1 that $5.56 \%$ of the AD patients from $\mathrm{NGH}$ and $27.78 \%$ of $\mathrm{AD}$ patients from SWH never consume fish. The majority of the subjects, both from the control and AD groups prefer to consume fish monthly. Compared to the control group, the consumption of $\omega-6$ and $\omega-3$ rich food was less in the $A D$ patients. None of the subjects consumed nuts, flaxseed, sesame oil, corn oil, or supplementary food (fish oil) daily, while the daily consumption rates of eggs, chicken, and red meat were higher in the control group. When control subjects from the two tested sites were compared, the consumptions of fish per week or per month, 
Table 1 Socio-demographic and health characteristics and dietary habit of studied subjects

\begin{tabular}{|c|c|c|c|c|}
\hline \multirow[t]{2}{*}{ Variables } & \multicolumn{2}{|c|}{$\begin{array}{l}\text { National Guard Health Affairs- King Abdulaziz Medical City, } \\
\text { Riyadh (NGH) }\end{array}$} & \multicolumn{2}{|c|}{$\begin{array}{l}\text { Social Welfare Homes for the Elderly } \\
\text { (SWH) }\end{array}$} \\
\hline & Control & Alzheimer & Control & Alzheimer \\
\hline \multicolumn{5}{|l|}{ Socio-demographic Characteristics } \\
\hline Age $($ mean $\pm S D)$ & $69.40 \pm 9.29$ & $76.00 \pm 13.05$ & $74.65 \pm 10.45$ & $80.17 \pm 8.33$ \\
\hline $\mathrm{BMI}($ mean $\pm \mathrm{SD})$ & $30.37 \pm 8.37$ & $24.23 \pm 8.49$ & $29.15 \pm 7.35$ & $28.49 \pm 5.06$ \\
\hline \multicolumn{5}{|l|}{ Education Level } \\
\hline Illiterate & $70 \%$ & $94.44 \%$ & $65 \%$ & $77.78 \%$ \\
\hline Elementary & $30 \%$ & $5.56 \%$ & $20 \%$ & $16.67 \%$ \\
\hline Intermediate & $0 \%$ & $0 \%$ & $15 \%$ & $5.56 \%$ \\
\hline Higher & $0 \%$ & $0 \%$ & $0 \%$ & $0 \%$ \\
\hline \multicolumn{5}{|l|}{ Income } \\
\hline Less than 3000 & $95 \%$ & $100 \%$ & $25 \%$ & $27.78 \%$ \\
\hline $3000-5000$ & $5 \%$ & $0 \%$ & $65 \%$ & $44.44 \%$ \\
\hline More than 5000 & $0 \%$ & $0 \%$ & $10 \%$ & $27.78 \%$ \\
\hline \multicolumn{5}{|c|}{ Chronic non communicable and health conditions } \\
\hline Diabetes & $30 \%$ & $22.2 \%$ & $20 \%$ & $27.78 \%$ \\
\hline Diabetes + Blood pressure & $20 \%$ & $38.89 \%$ & $40 \%$ & $44.44 \%$ \\
\hline Arthritis & $10 \%$ & $0 \%$ & $0 \%$ & $0 \%$ \\
\hline Heart Disease & $5 \%$ & $16.67 \%$ & $5 \%$ & $11.11 \%$ \\
\hline Any other & $4 \%$ & $5.56 \%$ & $2 \%$ & $0 \%$ \\
\hline Do know what is Alzheimer & $10 \%$ & $0 \%$ & $50 \%$ & $0 \%$ \\
\hline Do know what is $\omega-6$ and $\omega-3$ & $5 \%$ & $0 \%$ & $25 \%$ & $0 \%$ \\
\hline \multicolumn{5}{|l|}{ Dietary habit } \\
\hline \multicolumn{5}{|l|}{ Fish } \\
\hline Do not eat at all & $0 \%$ & $5.56 \%$ & $15 \%$ & $27.78 \%$ \\
\hline Everyday & $0 \%$ & $0 \%$ & $0 \%$ & $0 \%$ \\
\hline Per week & $60 \%$ & $33.33 \%$ & $30 \%$ & $22.22 \%$ \\
\hline Per month & $40 \%$ & $61.11 \%$ & $55 \%$ & $50 \%$ \\
\hline Egg/day & $65 \%$ & $45 \%$ & $75 \%$ & $25 \%$ \\
\hline Meat/day & $25 \%$ & $22 \%$ & $38 \%$ & $32 \%$ \\
\hline Chicken/day & $40 \%$ & $37 \%$ & $57 \%$ & $49 \%$ \\
\hline Nut/day & $0 \%$ & $0 \%$ & $0 \%$ & $0 \%$ \\
\hline Flaxseed /day & $0 \%$ & $0 \%$ & $0 \%$ & $0 \%$ \\
\hline Sesame oil/day & $0 \%$ & $0 \%$ & $0 \%$ & $0 \%$ \\
\hline Sunflower oil/ day & $55.55 \%$ & $44.50 \%$ & $70.75 \%$ & $29.25 \%$ \\
\hline Olive oil/day & $80.45 \%$ & $19.55 \%$ & $68.60 \%$ & $31.4 \%$ \\
\hline Corn oil/day & $0 \%$ & $0 \%$ & $0 \%$ & $0 \%$ \\
\hline Supplementary food (fish oil) & $0 \%$ & $0 \%$ & $0 \%$ & $0 \%$ \\
\hline
\end{tabular}

meat or chicken per day, and sunflower oil per day were found to be higher in subjects from SWH. When AD subjects from the two tested sites were compared, a greater percentage $(27.78 \%)$ of $\mathrm{AD}$ patients from SWH were found not to consume fish at all, and the consumption of eggs was also lesser in subjects from SWH than those from NGH.
Food and plasma fatty acid concentration

The fatty acid concentrations of various foods are shown in Table 2. Compared to the AD group, the concentrations of LA and total $\omega-6$ were higher $(p \leq 0.05)$ in the control group (both sites, NGH and SWH). Similarly, the concentrations of EPA, DHA, and $\omega-3$ were also slightly higher in the control group at both sites (NGH 
Table 2 Fatty acid profile of food in control and $A D^{*}$ patients

\begin{tabular}{|c|c|c|c|c|}
\hline \multirow[t]{2}{*}{ Fatty acid from Food (g/day) } & \multicolumn{2}{|c|}{$\begin{array}{l}\text { National Guard Health Affairs- King Abdulaziz Medical City, Riyadh } \\
(\mathrm{NGH})\end{array}$} & \multicolumn{2}{|c|}{$\begin{array}{l}\text { Social Welfare Homes for the Elderly } \\
\text { (SWH) }\end{array}$} \\
\hline & Control & Alzheimer & Control & Alzheimer \\
\hline LA (Linoleic acid; C18:2) & $31.77 \pm 2.902^{\mathrm{Aa}}$ & $25.21 \pm 2.221^{\mathrm{Bb}}$ & $30.80 \pm 3.0319^{\mathrm{Aa}}$ & $26.34 \pm 2.0249^{\mathrm{Bb}}$ \\
\hline AA (Arachidonic acid; C20:4) & $0.081 \pm 0.006^{\mathrm{Aab}}$ & $0.067 \pm 0.0015^{\mathrm{Bb}}$ & $0.077 \pm 0.0022^{\mathrm{Aab}}$ & $0.089 \pm 0.0060^{\mathrm{Aa}}$ \\
\hline ALA (a-linolenic acid; C18:3) & $0.924 \pm 0.0103^{\mathrm{Aa}}$ & $0.816 \pm 0.0240^{\mathrm{Aa}}$ & $0.920 \pm 0.0105^{\mathrm{Aa}}$ & $0.844 \pm 0.0216^{\mathrm{Aa}}$ \\
\hline EPA (Eicosapentaenoic acid; C20:5) & $0.050 \pm 0.0051^{\text {Aab }}$ & $0.023 \pm 0.0017^{\mathrm{Bb}}$ & $0.071 \pm 0.0075^{\mathrm{Aa}}$ & $0.052 \pm 0.0046^{\text {Aab }}$ \\
\hline DHA (Docosahexaenoic acid; C22:6) & $0.012 \pm 0.0005^{\mathrm{Aa}}$ & $0.007 \pm 0.0005^{\mathrm{Ba}}$ & $0.013 \pm 0.0006^{\mathrm{Aa}}$ & $0.013 \pm 0.0014^{\mathrm{Aa}}$ \\
\hline Total $\omega-6$ & $31.85 \pm 2.908^{\mathrm{Aa}}$ & $25.27 \pm 6.23^{\mathrm{Bb}}$ & $30.87 \pm 3.0332^{\mathrm{Aa}}$ & $26.43 \pm 2.0265^{\mathrm{Bb}}$ \\
\hline Total $\omega-3$ & $0.986 \pm 0.0117^{\mathrm{Aa}}$ & $0.846 \pm 0.0260^{\mathrm{Bb}}$ & $1.002 \pm 0.0126^{\mathrm{Aa}}$ & $0.909 \pm 0.0253^{\mathrm{Aab}}$ \\
\hline$\omega-6 / \omega-3$ & $32.30 \pm 2.279^{\mathrm{Aa}}$ & $29.86 \pm 2.552^{\mathrm{Aa}}$ & $30.80 \pm 3.0893^{\mathrm{Aa}}$ & $29.075 \pm 2.0848^{\mathrm{Aa}}$ \\
\hline
\end{tabular}

${ }^{*}$ AD-Alzheimer disease; Results are reported in mean \pm standard deviation

${ }^{\mathrm{ab}}$ Different superscripts denote a statistically significant difference between controls of two different places and between Alzheimer patients of two places

${ }^{\mathrm{AB}}$ Different superscripts denote a statistically significant difference between controls and Alzheimers patients of each place individually

and SWH), but the difference between the control and AD subjects was only significant $(p \leq 0.05)$ in subjects from NGH. We detected no significant difference in the $\omega-6 / \omega-3$ ratio when comparing the control and $A D$ groups at both sites (NGH and SWH). No significant differences (except EPA) were observed when the food fatty acid profiles of control subjects from both places were compared. Similarly, statistically insignificant $(p \geq 0.05)$ differences (except AA, EPA, and $\omega-3)$ were observed when the food fatty acid profiles of AD subjects from both sites were compared. Compared to the NGH, the concentrations of LA, AA, ALA, EPA, DHA, total $\omega-3$, and total $\omega-6$ were higher in AD patients recruited from $\mathrm{SWH}$.

In this study, comparing control and $\mathrm{AD}$ groups, we detected no statistically significant differences were detected in the mean level of the plasma fatty acid (Table 3). Similarly, difference's in the mean levels of plasma fatty (except EPA) was statistically insignificant $(p \geq 0.05)$ when comparing the NGH and SWH recruits, both control and AD.

\section{Correlation between dietary and plasma fatty acid concentrations}

In Table 4, the correlation between plasma fatty acid and dietary fatty acid intake has been calculated. The concentration of AA and EPA was correlated with their respective dietary intakes (measured by repeated $24 \mathrm{~h}$ records). The dietary intakes of ALA, $\omega-3$, and $\omega-6 / \omega-3$ were not correlated with their respective percentage in plasma lipids. No correlation was observed between the intake of $18 \mathrm{C}$ precursors ALA and the plasma levels of their long chain derivatives (AA, EPA, and DHA).

\section{Discussions}

In this study, the average age of women diagnosed with $\mathrm{AD}$ was more than 75 years, which was higher than the age reported in a previous study [20]. Age is the chief risk factor for $\mathrm{AD}[21,22]$ whereas the most important inherited determinants known for this disease were the family history of $\mathrm{AD}$ and the presence of ApoE4 genotype [23]. For all age groups, the most comorbid

Table 3 Fatty acid profile of plasma in control and $A D^{*}$ patients

\begin{tabular}{|c|c|c|c|c|}
\hline \multirow[t]{2}{*}{ Fatty acid from plasma (g/day) } & \multicolumn{2}{|c|}{$\begin{array}{l}\text { National Guard Health Affairs- King Abdulaziz Medical City, Riyadh } \\
\text { (NGH) }\end{array}$} & \multicolumn{2}{|c|}{$\begin{array}{l}\text { Social Welfare Homes for the Elderly } \\
\text { (SWH) }\end{array}$} \\
\hline & Control & Alzheimer & Control & Alzheimer \\
\hline LA (Linoleic acid; C18:2) & $2.423 \pm 0.1532^{\mathrm{Aa}}$ & $1.554 \pm 0.1500^{\mathrm{Aa}}$ & $1.899 \pm 1.001^{\mathrm{Aa}}$ & $01.756 \pm 0.1080^{\mathrm{Aa}}$ \\
\hline AA (Arachidonic acid; C20:4) & $0.019 \pm 0.0007^{\mathrm{Aa}}$ & $0.002 \pm 0.018^{\mathrm{Aa}}$ & $0.017 \pm 0.001^{\mathrm{Aa}}$ & $0.017 \pm 0.001^{\mathrm{Aa}}$ \\
\hline ALA (a-linolenic acid; C18:3) & $18.17 \pm 1.165^{\mathrm{Aa}}$ & $11.57 \pm 1.1400^{\mathrm{Aa}}$ & $14.24 \pm 0.7520^{\mathrm{Aa}}$ & $13.19 \pm 0.8085^{\mathrm{Aa}}$ \\
\hline EPA (Eicosapentaenoic acid; C20:5) & $0.158 \pm 0.0172^{\mathrm{Aa}}$ & $0.111 \pm 0.0086^{\text {Aab }}$ & $0.109 \pm 0.0067^{\text {Aab }}$ & $0.083 \pm 0.0032^{\mathrm{Ab}}$ \\
\hline DHA (Docosahexaenoic acid; C22:6) & $0.460 \pm 0.0421^{\mathrm{Aa}}$ & $0.377 \pm 0.0360^{\mathrm{Aa}}$ & $0.352 \pm 0.0206^{\mathrm{Aa}}$ & $0.403 \pm 0.0226^{\mathrm{Aa}}$ \\
\hline Total $\omega-6$ & $2.442 \pm 0.1536^{\mathrm{Aa}}$ & $1.572 \pm 0.1501^{\mathrm{Aa}}$ & $1.916 \pm 0.1001^{\mathrm{Aa}}$ & $1.773 \pm 0.1080^{\mathrm{Aa}}$ \\
\hline Total $\omega-3$ & $18.78 \pm 11.95^{\mathrm{Aa}}$ & $12.05 \pm 1.1738^{\mathrm{Aa}}$ & $14.71 \pm 0.7710^{\mathrm{Aa}}$ & $13.68 \pm 0.8284^{\mathrm{Aa}}$ \\
\hline$\omega-6 / \omega-3$ & $0.137 \pm 0.0021^{\mathrm{Ab}}$ & $0.174 \pm 0.0102^{\mathrm{Aa}}$ & $0.130 \pm 0.004^{\mathrm{Ab}}$ & $0.006 \pm 0.12^{\mathrm{Ab}}$ \\
\hline
\end{tabular}

*AD-Alzheimer disease

Results are reported in mean \pm standard deviation

${ }^{\mathrm{ab}}$ Different superscripts denote a statistically significant difference between controls of two different places and between Alzheimer patients of two places

A superscripts denote a statistically significant difference between controls and Alzheimers patients of each place individually 
Table 4 Correlation between consumption of food fatty acids with plasma fatty acid concentration

\begin{tabular}{|c|c|c|c|c|c|c|c|c|c|}
\hline \multirow[b]{2}{*}{ Plasma } & & \multicolumn{8}{|l|}{ Food } \\
\hline & & LA & AA & ALA & EPA & $\mathrm{DHA}$ & W6 & W3 & W6/W3 \\
\hline \multirow[t]{2}{*}{ LA } & Control & $-0.332^{*}$ & $-.374^{*}$ & 0.084 & $-0.378^{*}$ & -0.234 & $-0.421^{* *}$ & -0.030 & -0.102 \\
\hline & Alzheimer & $0.041^{*}$ & 0.105 & -0.012 & -0.014 & -0.040 & 0.074 & 0.036 & -0.022 \\
\hline \multirow[t]{2}{*}{ AA } & Control & 0.167 & 0.129 & 0.000 & 0.171 & 0.010 & 0.188 & -0.022 & 0.144 \\
\hline & Alzheimer & -0.060 & $0.373^{*}$ & -0.226 & -0.127 & -0.027 & $-0.493^{* *}$ & -0.230 & -0.049 \\
\hline \multirow[t]{2}{*}{ ALA } & Control & -0.336 & -0.200 & 0.227 & -0.443 & -0.081 & $-0.304^{*}$ & 0.133 & $-0.291^{*}$ \\
\hline & Alzheimer & 0.072 & 0.082 & 0.309 & -0.024 & 0.198 & -0.133 & 0.071 & 0.045 \\
\hline \multirow[t]{2}{*}{ EPA } & Control & 0.024 & 0.019 & 0.110 & $0.315^{* *}$ & 0.057 & -0.040 & 0.090 & -0.042 \\
\hline & Alzheimer & -0.033 & -0.167 & -0.155 & $0.198^{*}$ & 0.018 & $-0.416^{*}$ & -0.132 & 0.017 \\
\hline \multirow[t]{2}{*}{ DHA } & Control & -0.369 & -0.061 & 0.047 & -0.069 & $0.322^{* *}$ & -0.198 & -0.077 & -0.052 \\
\hline & Alzheimer & 0.091 & $0.290^{*}$ & 0.024 & 0.027 & 0.228 & 0.162 & 0.106 & -0.186 \\
\hline \multirow[t]{2}{*}{ W6 } & Control & $-0.32^{*}$ & -0.208 & 0.232 & $-0.443^{* *}$ & 0.035 & $0.350^{*}$ & 0.134 & $-0.325^{*}$ \\
\hline & Alzheimer & -0.188 & -0.009 & 0.192 & 0.104 & 0.117 & $0.055^{*}$ & 0.215 & -0.004 \\
\hline \multirow[t]{2}{*}{ W3 } & Control & $-0.339^{*}$ & -0.201 & 0.227 & $-0.444^{* *}$ & -0.076 & $-0.310^{* *}$ & 0.131 & $-0.292^{*}$ \\
\hline & Alzheimer & -0.077 & 0.081 & 0.003 & -0.028 & 0.209 & -0.136 & 0.065 & 0.039 \\
\hline \multirow[t]{2}{*}{ W6/W3 } & Control & 0.090 & 0.012 & -0.051 & -0.101 & $0.422^{* *}$ & -0.008 & 0.104 & -0.048 \\
\hline & Alzheimer & -0.159 & -0.090 & -0.042 & 0.024 & 0.036 & 0.215 & -0.036 & -0.222 \\
\hline
\end{tabular}

*Correlations significant at $P \leq 0.05$

${ }^{* *}$ Correlations significant at $P \leq 0.001$

diagnoses were diabetes, blood pressure, and cardiovascular diseases. Similar findings have been reported previously [24, 25]. Numerous chronic diseases, such as diabetes, hypertension, obesity, hyperlipidemia, and depression have been linked to $\mathrm{AD}[26,27]$. The applicability of each potential risk factor in moderating the age of onset or severity of $\mathrm{AD}$ development remains uncertain. It has been estimated that the threat of $\mathrm{AD}$ increases to between 50 and $65 \%$ in people with insulin resistance, particularly those with type 2 diabetes. Deficiency of insulin, besides impairing cognition, also seems to be involved in the formation of amyloid of plaque [28]. In the previous studies, various socioeconomic features [29], low education level [25, 30,31], smoking [32], and alcohol [33] were identifiable risk factors that decrease the quality of life of patients [34]. In this study, the majority of women suffering from $\mathrm{AD}$ were either illiterate or just passed elementary levels. In previous studies, it has been noted that higher education level is related to lower rates of dementia and tended to protect against it [35, 36]. Body mass index (BMI) either lower than 21 or higher than 29 might increase risk of dementia or cognitive decline $[37,38]$, which might be because high BMI is associated with a generally higher cardiovascular risk and lower BMI reflected the start of the dementia processes and is associated with a greater cortical amyloid burden [39].

Proper lifestyle behaviors, including good nutrition and physical activity, are the foremost requirement in preventing chronic diseases and disabilities in old age
[40, 41]. Cross-sectional studies provide evidence of the association between diet quality and prevalence of $\mathrm{AD}$ [42-44]. Dietary fat composition is an important factor in blood cholesterol profile and blood-brain barrier function and directs the significance of generating new dietary manipulation strategies to treat or prevent $\mathrm{AD}$ [45].

Malnourished AD patients or patients at risk of malnourishment were more impaired in basic and complex daily functioning than well-nourished $\mathrm{AD}$ patients, which suggests a relationship between nutritional status and basic and complex daily functioning in $\mathrm{AD}$ patients [46, 47]. Dietary parameters can be a potent tool for delaying the onset of AD or slowing its progression [45]. Various fatty acids, especially of exogenous origin ( $\omega-3$, $\omega-6$, trans, and odd-numbered fatty acids), might provide the best quantitative estimates of their intakes, which can be measured in various blood fractions and tissues, such as plasma, adipose tissue, and erythrocytes [48].

It has been found that the percentage of subjects consuming fish daily was very low. Several epidemiological studies have reported that reduced levels of $\omega-3$ fatty acids or reduced fish consumption are related to increased risk for age-related cognitive decline or dementia, such as $A D$ [49]. The protective effect of fish might have several alternative explanations, such as a higher fish intake indicates a healthier dietary pattern or higher socioeconomic status, which in turn is linked with better cognitive performance [50]. Another possible explanation is that higher intake of 
fish might be related to lower intake of another type of fat, such as saturated fat, and that fish is a good source of various other nutrients that might also contribute to cognitive function improvement [51]. EPA and DHA are mainly sourced from marine fish [52]. Although EPA and DHA can also be synthesized from ALA, the conversion efficiency of ALA to EPA varies between 0.2 and $21 \%$, and that of ALA to DHA varies between 0 and $9 \%[53,54]$. The concentration of plasma free fatty acids did not differ significantly across groups. In this study, it has been found that neither the concentration of free plasma DHA or ALA nor the concentration of omega 3 fatty acid was significantly lower in the AD group. Previously, it has been reported that DHA content in the brain is decreased in several neurodegenerative diseases [55], and significantly lower DHA levels were noticed in the blood plasma and brains of patients diagnosed with AD [56, 57]. Since DHA is a substrate of peroxisomal $\beta$-oxidation [58], it has been proposed that diminished plasma and tissue levels of DHA could be the consequence of peroxisomal dysfunction [55]. Reports from various epidemiological and observational studies show an inconsistent association between dietary intake of omega 3 fatty acids and the risk of dementia and AD. Some studies in humans have failed to find this association $[59,60]$, while other human studies indicate that increased intakes of omega 3 fatty acids from dietary sources are linked to a reduced risk of dementia and $\mathrm{AD}[61,62]$. In previous laboratory studies, animals fed diets enriched with n-3 PUFA had better regulation of neuronal membrane excitability $[63,64]$, greater fluidity of synaptic membranes [65], increased hippocampal nerve growth [66], and increased levels of neurotransmitters and higher density of neurotransmitter membrane receptors $[67,68]$, but the confirmation that plasma nutrient levels in $\mathrm{AD}$ are lower than in controls had thus far been lacking. This study shows that a large amount of EPA and DHA ingested came from food items other than fish, such as egg, meat, and oil, which is similar to the findings reported by Eissa et al. [69]. Samples were characterized by high linoleic acid intake and low $\alpha$-linolenic acid intake, which is also consistent with the literature [70, 71].

ALA and LA are physiologically essential and complementary, but they compete as a substrate for the same enzyme-desaturase. The conversion rate of precursors to long-chain derivatives also depends on the levels of the dietary intake of the long chain PUFA $[72,73]$. Conversion of ALA to longer chain fatty acid is reduced if the intake of ALA is too low. This is because it has to compete with the larger quantities of LA for the same enzyme. Since no correlation was detected between the dietary intakes of ALA and plasma levels of their respective bioconversion products, this suggests that the detected differences in the plasma levels of these long chains PUFA in our sample are determined by their habitual intake levels. This is probably due to the low conversion rate of linoleic and alpha-linolenic acids in humans [72]. Furthermore, the plasma levels of long-chain $\omega$-3 PUFA was negatively correlated with that of linoleic. Blood or tissue PUFA levels are expected to differ with their intake levels because $\omega-6$ or $\omega-3$ PUFAs is not biosynthesized de novo. In previous studies, to assess the relationship between the plasma level of individual PUFA and their intakes, a significant correlation was observed between the dietary intakes of long-chain n-3 fatty acids EPA and DHA with their plasma levels $[74,75]$.

\section{Conclusion}

The lower plasma level indicates lower impaired systemic availability of several nutrients. The finding shows that dietary intervention might play a role in the prevention of $\mathrm{AD}$. Although no significant difference in the plasma level of fatty acids between two groups (control and $\mathrm{AD}$ ) was observed, controlled subjects showed significantly higher intake of food rich in omega 3 fatty acids, which might support the fact that food and food supplement rich in omega 3 fatty acid (EPA and DHA) might delay the onset of AD. Education, income, overall health status, and the concentration of various fatty acids from food were higher and better in subjects SWH than NGH. This study is a small contribution to the search for an available and safe treatment for $\mathrm{AD}$. However, further research is required to verify the role of $n-3$ fatty acids as a protective agent against cognitive decline.

\section{Abbreviations \\ AA: Arachidonic acid; AD: Alzheimer disease; ALA: a linolenic acid; BMl: Body mass index; DHA: Docosahexaenoic acid; EPA: Eicosapentaenoic acid; LA: Linoleic acid; MUFA: monounsaturated fatty acid; NGH: National Gaurd Health Affairs-King Abdulaziz Medical City, Riyadh; PUFA: Polyunsaturated fatty acid; SWH: Social Welfare Homes for Elderly}

\section{Acknowledgements}

Authors would like to thank all participants in this study. This research project was supported by "Research Center of the Female Scientific and Medical Colleges", Deanship of Scientific Research, King Saud University.

\section{Funding}

This study was funded by King Abdulaziz City for Science and technology (A-B-36-276).

\section{Availability of data and materials}

The data generated or analyzed during this study are included in this published article.

\section{Authors' contributions}

In this study, SBRS and DMN, did the study design and performed the experiments. MMS and SBRS collected data. MFSD did statistical analyses. MFSD, SBRS, DMN and SA interpreted results. SA wrote manuscript and DMN functioned as corresponding author. All authors have reviewed and approved the final manuscript.

\section{Ethics approval and consent to participate}

This study was conducted in compliance with the ethical principle of the Declaration of Helsinki. The study was approved by King Abdullah International Medical Research Center (Reference \#: IRBC/614/14) and study was in accordance 
with the Policy of Research Centre. The aim of this study was explained to all participants. Written consent was obtained from the respondents involved in this research and the study abided by the principle of voluntary participation. Blood was withdrawn by a qualified nurse and subjects were assured that the information given was entirely for scientific purposes and would be kept confidential.

\section{Consent for publication}

All co-authors and participants have given their consent for publication of this article in Lipids in Health and Disease.

\section{Competing interests}

The authors declare that they have no competing interests.

\section{Publisher's Note}

Springer Nature remains neutral with regard to jurisdictional claims in published maps and institutional affiliations.

\section{Author details}

${ }^{1}$ Department of Food and Nutrition Sciences, College of Food and Agriculture Sciences, King Saud University, Riyadh-11495, P.O. 11495, Riyadh, Saudi Arabia. ${ }^{2}$ Department of Nutrition and Food Science, Faculty of Home Economics, Menoufia University, Shebin El Kom, Egypt.

\section{Received: 21 October 2018 Accepted: 21 March 2019}

Published online: 30 March 2019

\section{References}

1. Cole GM, Lim GP, Yang F, Teter B, Begum A, Ma Q, Harris-White ME Frautschy SA. Prevention of Alzheimer's disease: Omega-3 fatty acid and phenolic anti-oxidant interventions. Neurobiol Aging. 2005;26(Suppl 1):133-6.

2. Kumar A, Singh A. Ekavali. A review on Alzheimer's disease pathophysiology and its management: an update. Pharmacol Rep. 2015;67:195-203.

3. Thomas J, Thomas CJ, Radcliffe J, Itsiopoulos C. Omega-3 fatty acids in early prevention of inflammatory neurodegenerative disease: a focus on alzheimer's disease. Bomed Res Int. 2015;2015:172801.

4. Holmes C. Review: systematic inflammation and Alzheimer's disease Neuropathol Appl Neurobiol. 2013;39:51-68.

5. Brookmeyer R, Johnson E, Ziegler-Graham K, Arrighi HM. Forecasting the global burden of Alzheimer's disease. Alzheimers Dement. 2007:3:186-91.

6. Bennett DA, Evans DA. Alzheimers disease. Dis Mon. 1992:38:1-64.

7. Shim KS, Drebrin LG. Debrin, a dendritic spine protein is manifold decreased in brains of patients with Alzheimer's disease and Down syndrome. Neurosci Lett. 2002;324:209-12

8. Farquharson J, Cockburn F, Patrick WA, Jamieson EC, Logan RW. Infant cerebral cortex phospholipid fatty-acid composition and diet. Lancet. 1992; 340:810-3.

9. Byard RW, Makrides M, Need M, Neumann MA, Gibson RA. Sudden infant death syndrome: effect of breast and formula feeding on frontal cortex and brainstem lipid composition. J Paediatr Child Health. 1995;31:14-6.

10. Greiner RC, Winter J, Nathanielsz PW, Brenna JT. Brain docosahexaenoate accretion in fetal baboons: bioequivalence of dietary alpha-linolenic and docosahexaenoic acids. Pediatr Res. 1997;42:826-34.

11. Vercambre MN, Grodstein F, Kang JH. Dietary fat intake in relation to cognitive change in high-risk women with cardiovascular disease or vascular factors. Eur J Clin Nutr. 2010:64:1134-40.

12. Morris MC, Evans DA, Bienias JL, Tangney CC, Bennett DA, Aggarwal N, Schneider J, Wilson RS. Dietary fats and the risk of incident Alzheimer disease. Arch Neurol. 2003;60:194-200.

13. Luchsinger JA, Tang MX, Shea S, Mayeux R. Caloric intake and the risk of Alzheimer disease. Arch Neurol. 2002;59:1258-63.

14. Devi MMLT. Prevalence of anemia and knowledge regarding anemia among reproductive age women. IOSR JNHS. 2014;3:54-60.

15. WHO EC. Appropriate body-mass index for Asian populations and its implications for policy and intervention strategies. Lancet. 2004:363:157-63.

16. Posner BM, Smigelski C, Duggal A, Morgan JL, Cobb J, Cupples LA Validation of two-dimensional models for estimation of portion size in nutrition research. J Am Diet Assoc. 1992;92:738-41.

17. Cypel YS, Guenther PM, Petot GJ. Validity of portion size measurement aids: a review. J Am Diet Assoc. 1997;97:289-92.
18. Biro G, Hulshof KF, Ovesen L, Amorim Cruz JA, EFCOSUM Group. Selection of methodology to assess food intake. Eur J Clin Nutr. 2002;56:S25-32.

19. Folch J, Lees M, Sloane Stanley GH. A simple method for the isolation and purification of total lipids from animal tissues. J Biol Chem. 1957; 226:497-509.

20. Vale FA, Miranda SJ. Clinical and demographic features of patients with dementia attended in a tertiary outpatient clinic. Arq Neuro Psiquiatr. 2002; 60:548-52.

21. Von Strauss E, Viitanen M, De Ronchi D, Winblad B, Fratiglioni L. Aging and the occurrence of dementia: findings from a population based cohort with a large sample of nonagenarians. Arch Neurol. 1999;56:587-92.

22. Citron M. Alzheimer's disease: treatments in discovery and development Nat Neurosci. 2002;5(Suppl):1055-7.

23. Fratilioni L, Ahlbom A, Viitanen M, Winblad B. Risk factors for late onset Alzheimer's disease: a population based, case control study. Ann Neurol. 1993;33:258-66

24. Jelastopulu E, Giourou E, Argyropoulos K, Kariori E, Moratis E, Mestousi A, Kyriopoulos J. Demographic and clinical characteristics of patients with dementia in Greece. Adv Psychiatry. 2014:2014:1-7.

25. Park MH, Smith SC, Neuburger J, Chrysanthaki T, Hendrik AAJ, Black N. Sociodemographic characteristics, cognitive function, and health-related quality of life of patients referred to memory assessment services in England. Alzheimer Dis Assoc Disord. 2017;31:159-67.

26. Barnard ND, Bush Al, Ceccarelli A, Cooper J, de Jager CA, Erickson Kl, Fraser G, Kesler S, Levin SM, Lucey B, Morris MC, Squitti R. Dietary and lifestyle guidelines for the prevention of Alzheimer's disease. Neurobiol Aging. 2014;35:S74-8.

27. Norton S, Matthews FE, Barnes DE, Yaffe K, Brayne C. Potential for the primary prevention of Alzheimer's disease: an analysis of population based data. Lancet Neurol. 2014;13:788-94.

28. De la Monte SM. Type 3 diabetes is sporadic Alzheimer's disease: mini review. Eur Neuropsychopharmacol. 2014;24:1954-60.

29. Alzheimer's Association. Alzheimer's disease facts and figures. Alzheimers Dement. 2010;6:158-94.

30. Evans DA, Hebert LE, Beckett LA, Scher PA, Albert MS, Chown MJ, Pilgrim DM, Taylor JO. Education and other measures of socioeconomic status and risk of incident Alzheimer disease in a defined population of older persons. Arch Neurol. 1997;54:1399-405

31. Plassman BL, Langa KM, Fisher GG, Heeringa SG, Weir DR, Ofstedal MB, Burke JR, Hurd MD, Potter GG, Roodgers WL, Steffens DC, Willis RJ, Wallace RB. Prevalence of dementia in the United States: the aging, demographics, and memory study. Neuroepidemiol. 2007;29:125-32.

32. Anstey KJ, Sanden C, Salim A, O'Kearney R. Smoking as a risk factor for dementia and cognitive decline: a meta-analysis of prospective studies. Am J Epidemiol. 2007;166:367-78.

33. Agarwal DP. Cardioprotective effects of light-moderate consumption of alcohol: a review of putative mechanisms. Alcohol Alcohol. 2002;37:409-15.

34. Nunes B, Silva RD, Cruz VT, Roriz JM, Pais J, Silva MC. Prevalence and pattern of cognitive impairment in rural and urban populations from northern Portugal. BMC Neurol. 2010;10:1-12.

35. Perls T. Centenarians who avoid dementia. Trends Neurosci. 2004;27:633-6.

36. Mortimer JA, Borenstein AR, Gosche KM, Snowdon DA. Very early detection of Alzheimer neuropathology and the role of brain reserve in modifying its clinical expression. J Geriatr Psychiatry Neurol. 2005;18:218-23.

37. Brubacher D, Monsch AU, Stähelin HB. Weight change and cognitive performance. Int J Obes. 2004:28:1163-7.

38. Buchman AS, Wilson RS, Bienias JL, Shah RC, Evans DA, Bennet DA. Change in body mass index and risk of incidence of Alzheimer disease. Neurology. 2005;65:892-7.

39. Hsu DC, Mormin EC, Schultz AP, Amariglio RE, Donovan NJ, Rentz DM Johnson KA, Sperling RA, Marshall GA, Study HAB. Lower late-life body-mass index is associated with higher cortical amyloid burden in clinically normal elderly. J Alzheimers Dis. 2016:53:1097-105.

40. Sebastiani P, Perls $\Pi$. The genetics of extreme longevity: lessons from the New England centenarian study. Front Genet. 2012:3:1-5.

41. Lovden $M, X u W$, Wang HX. Lifestyle change and the prevention of cognitive decline and dementia: what is the evidence? Curr Opin psychiatry. 2013;26:239-43.

42. Shatenstein B, Kergoat MJ, Reid I. Poor nutrient intakes during 1 year follow up with community dwelling older adults with early stage Alzheimer dementia compared to cognitively intact matched controls. J Am Diet Assoc. 2007:107: 2091-9. 
43. Gu Y, Nieves JW, Stern Y, Luchsinger JA, Scarmeas N. Food combination and Alzheimer disease risk: a protective diet. Arch Neurol. 2010;67:699-706.

44. Lopez LB, Kritz-Silverstein D, Barrett CE. High dietary plasma levels of omega 3 fatty acid docosahexanoic acid are associated with decreased dementia risk: the rancho bernardo study. J Nutr Health Aging. 2011;15:25-31.

45. Iuliano L, Pacelli A, Ciacciarelli M, Zerbinati C, Fagioli S, Piras F, Orfei MD, Bossu P, Pazzelli F, Serviddio G, Caltagirone C, Spalleta G. Plasma fatty acid lipidomics in amnestic mild cognitive impairment and Alzheimers disease. J Alzheimers Dis. 2013:36:545-53.

46. Guerin O, Soto ME, Brocker P, Robert PH, Benoit M, Vellas B. REAL FR group, nutritional status assessment during Alzheimer's disease: results after one year (the real French study group). J Nutr Health Aging. 2005;9:81-4

47. Spaccavento S, Del Prete M, Craca A, Fiore P. Influence of nutritional status on cognitive, functional and neuropsychiatric deficits in Alzheimer's disease. Arch Gerontol Geriatr. 2009;48:356-60.

48. Baylin A, Campos $H$. The use of fatty acid biomarkers to reflect dietary intake. Curr Opin Lipidol. 2006;17:22-7.

49. Huang TL. Omega 3 fatty acid, cognitive decline and Alzheimer's disease: a critical review and evaluation of the literature. J Alzheimers Dis. 2010;21:673-90.

50. Kesse-Guyot E, Andreeva VA, Jeandel C, Ferry M, Hercberg S, Galan P. Healthy dietary pattern at midlife is associated with subsequent cognitive performance. J Nutr. 2012;142:909-15.

51. Ortega RM, Requejo AM, Andres P, Lopez Sobaler AM, Quintas ME, Redondo MR, Navia B, Rivas T. Dietary intake and cognitive function in a group of elderly people. Am J Clin Nutr. 1997;66:803-9.

52. Kris Etherton PM, Grieger JA, Etherton TD. Dietary reference intakes for DHA and EPA. Prostaglandins Leukot Essent Fatty Acids. 2009;81:99-104.

53. De Filippis AP, Sperling LS. Understanding omega 3s. Am Heart J. 2006;151: 564-70.

54. Williams CM, Burdge G. Long chain n3 PUFA: plant v. Marine sources. Proc Nutr Soc. 2006;65:42-50.

55. Lizard G, Rouaud O, Demarquoy J, Cherkaoui-Malki M, luliano L. Potential roles of peroxisomes in Alzheimers disease and in dementia of the Alzheimers type. J Alzheimers Dis. 2012;29:241-54

56. Conquer JA, Tierney MC, Zecevic J, Bettger WJ, Fisher RH. Fatty acid analysis of blood plasma of patients with Alzheimer's disease and other type of dementia and cognitive impairment. Lipids. 2000;35:1305-12.

57. Plourde M, Fortier M, Vandal M, Treamblay-Mercier J, Freemantle E, Begin M, Pifferi F, Cunnane SC. Unresolved issues in the link between docosahexaenoic acid and Alzheimers disease. Prostaglandins Leukot Essent Fatty Acids. 2007;7:301-8.

58. Wanders RJ, Waterham HR. Biochemistry of mammalian peroxisomes revisited. Annu Rev Biochem. 2006;75:295-332

59. Engelhart MJ, Geerlings MI, Ruitenberg A, Van Swieten JC, Hofman A, Witteman JC, Breteler MM. Diet and risk of dementia: does fat mater? The Rotterdam Study Neurology. 2002;59:1915-21.

60. Schaefer EJ, Bongard V, Beiser AS, Lamon-fava S, Robins SJ, Au R, Tucker KL, Kyle DJ, Wilson PW, Wolf PA. Plasma phosphatidylcholine docosahexaenoic acid content and risk of dementia and Alzheimer disease: the Framingham heart study. Arch Neurol. 2006;63:1545-50.

61. Morris MC, Evans DA, Bienias JL, Tangney CC, Benett DA, Wilson RS, Aggarwal N, Schneider J. Consumption of fish and n-3 fatty acids and risk of incident Alzheimer disease. Arch Neurol. 2003;60:940-6.

62. Barberger Gaetau P, Jutand M, Letenneur L, Larrieu S, Tavernier B, Berr C. 3C study group. Correlates of regular fish consumption in French elderly community dwellers: data from three city study. Eur J Clin Nutr. 2005;59:817-25.

63. Young C, Gean PW, Chiou LC, Shen YZ. Docosahexaenoic acid inhibits synaptic transmissions and epileptiform activity in the rat hippocampus. Synapse. 2000;37:90-4.

64. Itokazu N, Ikegaya Y, Nishikawa M, Matsuki N. Bidirectional actions of docosahexaenoic acid on hippocampal neurotransmissions in vivo. Brain Res. 2000;862:211-6.

65. Suzuki H, Park SJ, Tamura M, Ando S. Effect of long term feeding of dietary lipids on the learning ability, fatty acid composition of brain stem phospholipids and synaptic membrane fluidity in adult mice: a comparison of sardine oil diet with palm oil diet. Mech Ageing Dev. 1998;101:119-28.

66. Ikemoto A, Nitta A, Furukawa S, Ohisi M, Nakamura A, Fujii Y, Okuyama H. Dietary n-3 fatty acid deficiency decreases nerve growth factor content in rat hippocampus. Neurosci Lett. 2000;285:99-102.

67. De la Presa OS, Innis SM. Diverse, region specific effects of addition of arachidonic and docosahexaenoic acids to formula with low or adequate linoleic and a linolenic acids on piglet brain mono aminergic neurotransmitters. Pediatr Res. 2000;48:125-30.

68. Innis SM. The role of dietary n-6 and n-3 fatty acids in the developing brain. Dev Neurosci. 2000;22:474-80.

69. Eissa AM, Saleh AOL, Abdel Aal ZA, Anwar MM, Samy MA. Impact of a diet rich in n-3 fatty acids on Alzheimer disease. Egypt J Psychiatr. 2013;34:61-8.

70. Astorg P, Arnault N, Czernichow S, Noisette N, Galan P, Hercberg S. Dietary intakes and food sources of n-6 and n-3 PUFA in French adult men and women. Lipids. 2004;39:527-35.

71. Astorg P, Bertais S, Laporte F, Arnault N, Estaquio C, Galan P, Favier A, Hercberg S. Plasma n-6 and n-3 polyunsaturated fatty acids as biomarkers of their dietary intakes: a cross-sectional study within a cohort of middle-aged French men and women. Eur J Clin Nutr. 2008;62:1155-61.

72. Burdge G. Alpha-linolenic acid metabolism in men and women: nutritional and biological implications. Curr Opin Clin Nutr Metab Care. 2004;7:137-44.

73. Burdge GC, Calder PC. Conversion of alpha-linolenic acid to longer-chain polyunsaturated fatty acids in human adults. Reprod Nutr Dev. 2005;45:581-97.

74. Amiano P, Dorronsoro M, de Renobales M, Ruiz de Gordoa JC, Irigoyen I, EPIC group of Spain. Very-long-chain omega-3 fatty acids as markers for habitual fish intake in a population consuming mainly lean fish: the EPIC cohort of Gipuzkoa. European prospective investigation into cancer and nutrition. Eur J Clin Nutr. 2001:55:827-32.

75. Kuriki K, Nagaya T, Tokudome Y, Imaeda N, Fujiwara N, Sato J, Goto C, Ikeda M, Maki S, Tajima K, Tokudome S. Plasma concentrations of n-3 highly unsaturated fatty acids are good biomarkers of relative dietary fatty acid intakes: a cross-sectional study. J Nutr. 2003;133:3643-50.

\section{Ready to submit your research? Choose BMC and benefit from:}

- fast, convenient online submission

- thorough peer review by experienced researchers in your field

- rapid publication on acceptance

- support for research data, including large and complex data types

- gold Open Access which fosters wider collaboration and increased citations

- maximum visibility for your research: over $100 \mathrm{M}$ website views per year

At BMC, research is always in progress.

Learn more biomedcentral.com/submissions 